\title{
ARENA OLAHRAGA ELEKTRONIK DI SETIABUDI
}

\author{
Fransiskus $^{1)}$, Mieke Choandi $^{2)}$ \\ 1) Program Studi S1 Arsitektur, Fakultas Teknik, Universitas Tarumanagara, fransformers@gmail.com \\ 2) Program Studi S1 Arsitektur, Fakultas Teknik, Universitas Tarumanagara, mieke@untar.ac.id
}

\begin{abstract}
Abstrak
Jakarta pada era yang serba modern dan kompleks seperti saat ini, generasi millennialnya sudah terbiasa untuk tumbuh dan berkembang di era digital yang kini berperan sebagai arus ruang gerak baru dalam kehidupannya masyarakatnya. Era digital pun secara perlahan tumbuh sebagai bagian dari karya, budaya, dan proses yang tidak dapat terlepas dari perjalanan kehidupan manusia. Namun, dalam pemenuhan kebutuhan sosialnya, teknologi digital sering kali hanya dimanfaatkan sebagai komponen media yang dalam prosesnya dilakukan secara sekunder di mana memiliki kecenderungan untuk memancing perubahan moral ke arah individualistis. Dalam pemenuhan kebutuhan sosial di era digital tersebut, maka dibutuhkan wadah sosial sebagai wadah yang tidak membiarkan arus era digital mengalir begitu saja, tetapi berbicara mengenai bagaimana cara mengontrol arus digital itu sendiri. Dari hal tersebut, arsitektur berbicara tentang cara untuk memenuhi kebutuhan komunitas digital sebagai sarana eksistensi mereka. Karena bagaimanapun juga manusia tetap membutuhkan sifat komunikasi face-to-face yang melalui proses secara primer. Melalui isu tersebut, Setiabudi merupakan salah satu kawasan yang cocok dengan isu sosial digital dan individualisme yang kini berkembang dengan cepat di kawasan tersebut. Pendekatan penyelesaian masalah tersebut melalui pendekatan teori third place dalam arsitektur. Dengan memperhatikan kondisi sosial-ekonomi dan kebiasaan warga sekitar serta fenomena-fenomena yang ada, dapat ditemukan penyelesaian masalah yang selaras dengan perkembangan industri 4.0, yaitu melalui pembangunan fasilitas arena olahraga elektronik yang bersifat third place di kawasan tersebut.
\end{abstract}

Kata kunci: digital; millenial; sosial; individualisme

\begin{abstract}
Jakarta in an era that is as modern and complex as it is today, the millennial generation is accustomed to growing and developing in the digital era which now serves as a new movement of space in the lives of its people. The digital age is slowly growing as part of the work, culture, and processes that can not be separated from the journey of human life. However, in meeting their social needs, digital technology is often only used as a component of the media which is done in a secondary process which has a tendency to provoke moral change toward individualism. In fulfilling social needs in the digital age, a social container is needed as a container that does not let the flow of the digital era just flow, but talks about how to control the digital flow itself. From this, architecture talks about ways to meet the needs of the digital community as a means of their existence. Because after all humans still need the nature of face-to-face communication through the primary process. Through these issues, Setiabudi is one area that is suitable for digital social issues and individualism which is now developing rapidly in the region. The approach to solving these problems is through a third place theory approach in architecture. By paying attention to the socio-economic conditions and habits of the surrounding residents and the phenomena that can be found, problem solving is in line with the development of industry 4.0, namely through the construction of electronic sports arena facilities that are third place in the region.
\end{abstract}

Key word: digital; millenial; social; individualism 


\section{PENDAHULUAN}

Padatnya aktivitas di Kota Jakarta yang modern membuat masyarakatnya seperti kehilangan waktu untuk beristirahat. Hampir semua waktu yang ada harus digunakan seefisien mungkin untuk menghasilkan keuntungan pribadi. Hal ini dikarenakan setiap individu yang tinggal di kota harus bersaing (iklim kompetitif) agar tidak mengalami ketertinggalan dengan individu lainnya. Akibatnya kehidupan sosial masyarakat jakarta menjadi terabaikan karena mereka lebih fokus kepada urusan pribadinya sendiri. Menurut Sumardjito (1999), fenomena ini lazim muncul di perkotaan besar dan biasa disebut sebagai sikap individualisme.

Salah satu daerah yang sangat identik dengan kehidupan modern dan padat aktivitas di bidang bisnis adalah Kecamatan Setiabudi, Jakarta Selatan. Kecamatan Setiabudi berada di antara kawasan Segitiga Emas Jakarta yang membuatnya menjadi salah satu lokasi strategis penduduk Jakarta khususnya para pekerja perkantoran. Lokasi ini terdiri dari sebagian besar pemukiman rendah yang dikelilingi oleh gedung-gedung perkantoran. Terdapat beberapa komplek Central Business District $(C B D)$ di kecamatan ini diantaranya adalah sebagian Mega Kuningan, sebagian Rasuna Epicentrum serta Kuningan Persada. Dikarenakan Segitiga Emas sendiri merupakan kawasan dengan pertumbuhan bisnis tercepat se-Asia-Pasifik membuat Kecamatan Setiabudi menjadi lokasi strategis bisnis dan tempat tinggal akibat terkena imbas pertumbuhan bisnis dari Segitiga Emas. Sehingga kecamatan ini memiliki identitas sebagai salah satu kawasan bisnis Kota Jakarta.

Keberadaan Kecamatan Setiabudi yang dihimpit oleh keberadaan Segitiga Emas dan dikelilingi oleh proyek-proyek prestisius seperti MRT dan LRT membuat kawasan ini sangat banyak dikunjungi oleh berbagai masyarakat sekitar Jabodetabek, terlebih lagi lokasinya yang berada di pusat kota. Dengan dikelilingi oleh gedung-gedung perkantoran bertingkat tinggi serta berbagai sentra komersial membuat kehidupan dikawasan ini menjadi sangat padat aktivitas. Kepadatan aktivitas ini bisa memicu kehidupan masyarakat khususnya yang berada di kecamatan ini semakin individualis. Terlebih lagi kawasan ini dipenuhi oleh rumah-rumah kost yang penghuninya datang dari luar kecamatan setiabudi yang tidak saling mengenal dengan warga lokal ataupun dengan sesama warga pendatang. Sehingga karakteristik masyarakatnya cenderung semakin hilang dengan semakin banyaknya warga pendatang dan perginya warga lokal.

Segitiga Emas sebagai 'magnet' kawasan bisnis membuat berbagai fasilitas penunjang kawasan bisnis tumbuh begitu banyak dan sangat cepat sebagai kebutuhan dari para pekerja dan masyarakat sekitarnya. Sayangnya keberadaan fasilitas di bidang sosial masih sangat minim dan cenderung kalah bersaing pertumbuhannya . Dari hasil pengamatan, kawasan ini tidak memiliki area publik yang didedikasikan sebagai area komunal bagi warganya. Kebanyakan warga memanfaatkan lokasi-lokasi yang tidak lazim sebagai area komunal mereka seperti jalan komplek, trotoar, taman pembatas jalan, dsb.

Namun wadah-wadah aktivitas sosial warga tersebut merupakan salah satu alat pengendali dari penyebaran sikap individualisme. Sayangnya dimasa yang akan datang, kemungkinan wadah-wadah aktivitas sosial di kawasan ini akan berkurang, khususnya yang tidak sesuai peruntukan, sebagai akibat pengembangan wilayah dan infrastruktur kota. Untuk itu sangat diperlukan berbagai cara untuk mempertahankan ataupun meningkatkan aktivitas warga melalui wadah-wadah interaksi yang sesuai dengan kebutuhan masyarakat serta sesuai dengan pengembangan kota, khususnya di kawasan ini.

Menurut Syani (2012), pada dasarnya, manusia diciptakan sebagai makhluk multidimensional yang memiliki kemampuan berinteraksi dan bertindak sebagai makhluk individu maupun sosial. Sebagai individu, manusia dapat melakukan komunikasi secara pribadi berdasar 3 poin utama, yaitu persepsi terhadap diri pribadi, kesadaran pribadi, dan pengungkapan diri. Hal tersebut menjadi wajar karena adanya unsur karakteristik dan jati diri yang berbeda di setiap diri manusia. Namun dalam perjalanannya, manusia tidak dapat terusmenerus berperan sebagai individu, manusia sebagai makhluk sosial juga membutuhkan ruang tersendiri sebagai bagian dari proses perkembangan. 
Hal ini tidak terkecuali juga dibutuhkan oleh masyarakat generasi millennial, salah satunya adalah Jakarta. Pada era yang serba modern dan kompleks seperti saat ini, generasi millennial perkotaan sudah terbiasa untuk tumbuh sebagai era digital yang berperan untuk menjadi arus ruang gerak baru di dalam kehidupannya sebagai makhluk individu dan sosial. Era digital pun secara perlahan tumbuh sebagai bagian dari karya, budaya, dan proses yang tidak dapat terlepas dari perjalanan kehidupan manusia. Namun, dalam pemenuhan kebutuhan sosialnya, teknologi digital sering kali hanya dimanfaatkan sebagai komponen media yang dalam prosesnya dilakukan secara sekunder di mana memiliki kecenderungan untuk memancing perubahan moral ke arah individualistis.

Dalam pemenuhan kebutuhan sosial di era digital tersebut, maka dibutuhkan wadah sosial sebagai wadah yang tidak membiarkan arus era digital mengalir begitu saja, tetapi berbicara mengenai bagaimana cara mengontrol arus digital itu sendiri. Dari hal tersebut, arsitektur berbicara tentang cara untuk memenuhi kebutuhan komunitas digital sebagai sarana eksistensi mereka. Karena bagaimanapun juga manusia tetap membutuhkan sifat komunikasi face-to-face yang melalui proses secara primer.

\section{KAJIAN LITERATUR \\ Third place}

Dalam buku karya Ray Oldenberg (1989), Third place berkontribusi pada kehidupan yang layak dijalani. mereka memberi kita identitas; mereka memulihkan kita; mereka mendukung kita. Intinya: Mereka memungkinkan kita menjadi kita. Dan semua orang tahu nama kita. Ray Oldenberg (1989), Third place merupakan tempat orang berkumpul selain bekerja atau di rumah. Seperti dijelaskan oleh Oldenburg, Third place yang dimaksud, yaitu: 1) mereka netral, artinya semua orang bisa datang dan pergi tanpa penalti. Jika Anda tidak pergi ke Third place Anda selama beberapa hari atau minggu, kembalinya anda disambut dengan rasa minat dan antusiasme; 2) perbedaan status yang sangat penting di tempat lain tidak relevan. Dan tidak ada yang memainkan tuan rumah di tempat ketiga; 3) Percakapan adalah kegiatan utama di tempat ketiga, dan salah satu dari beberapa cara untuk menyinggung orang lain yang hadir adalah menjadi membosankan; 4) Tempat ketiga dapat diakses, artinya mereka memiliki jam yang panjang dan mudah dijangkau; 5) Tempat ketiga memiliki pengunjung tetap. Memang, pelanggan tetap menentukan tempat ketiga, tetapi orang baru diterima, tidak secara otomatis tetapi sering dengan mudah; 6) Tempat ketiga secara fisik sederhana dan tidak berlebihan; 7) Suasana dominan dari tempat ketiga adalah menyenangkan.

\section{E-Sport (Olahraga Elektronik)}

Wagner (2006) menyediakan definisi secara detail mengenai esport t sebagai "area dari aktivitas olahraga dimana orang mengembangkan dan melatih mental dan kemampuan fisik dalam penggunaan teknologi informasi dan komunikasi" (didapat dari Banyai,2018, h. 3). Hemphill (2005) menambahkan bahwa esport merupakan "realita olahraga alternatif, yaitu atlet dengan perluasan secara elektronik yang mewakili dunia olahraga di bidang digital (didapat dari Banyai,2018, h.3)." Secara pragmatis, esport telah didefinisikan sebagai "istilah payung yang digunakan untuk mendeskripsikan kompetisi video game yang terorganisir dan tersetujui, umumnya dalam konteks turnamen viedo game"(Whalen, 2013) (didapat dari Banyai,2018, h. 3). Menurut definisi dan deskripsi di atasm esport merupakan olahraga alternatif dan sebagai cara spesial dalam menggunakan video game serta perlibatan dalam cara bermainnya. Menurut majalah Forbes (2013), meski kompetisi teroganisasi telah lama menjadi bagian dari budaya permainan video, kompetisi ini telah mengalami peningkatan besar dalam popularitas dari akhir dekade 2000-an dan awal 2010-an. Jika kompetisi di dekade 2000-an kebanyakan diikuti oleh para pemain amatir, pengadaan kompetisi profesional dan meningkatnya pemirsa saat ini mendukung munculnya banyak pemain dan tim profesional secara signifikan, dan banyak pengembang permainan video saat ini membangun permainan dengan corak untuk memfasilitasi kompetisi tersebut. (Forbes, 2013). 


\section{E-Sport Arena}

Menurut Prescot (2019) dalam "2019-2020 Guide to Esport", E-Sport Arena merupakan wadah pertandingan yang dikhususkan untuk pertandingan E-Sport dengan tujuan untuk dipertontonkan pertandingannya oleh para penonton/penggemar E-Sport itu sendiri. Pertandingan tersebut menggunakkan fasilitas-fasilitas digital seperti Live Streaming, panggung, bentang lebar, pencahayaan dan audio khusus, proyektor dsb. yang dapat diskalakan dengan kebutuhannya agar penonton bisa menyaksikan pertandingan di dalam game tersebut. Bagi Penontonnya keberadaan arena E-Sport ini bertujuan untuk mendekatkan mereka dengan pemainnya secara langsung.

\section{METODE}

\section{Metode Pengumpulan Data}

1) Studi Literatur:

a) studi-studi mengenai teori Third place; b) Literatur E-Sport di bidang arsitektur;

2) Studi preseden: berupa proyek-proyek terkait E-Sport dan Third place;

3) Pengamatan lingkungan:

a) Mencari pusat-pusat kegiatan yang ada serta mendata kegiatan yang ada didalamnya dalam satuan waktu tertentu

b) Mengamati kualitas aktivitas yang terjadi disetiap pusat kegiatan;

c) Mendata Transportasi untuk menggapai lokasi;

d) Mencari sejarah dan keunikan daerah yang diamati; e) Wawancara dengan narasumber kunci di kawasan;

4) Metode pengamatan:

a) Survey lapangan, b) Pengambilan foto

\section{Metode Perancangan}

Mengamati berbagai kejadian yang ada di lokasi pengamatan hingga menemukan esensi dari arsitektur itu sendiri yang berkembang di kawasan tersebut (Fenomenologi, Genius Loci).

\section{DISKUSI DAN HASIL \\ Batasan Proyek}

Setiabudi E-Sport Arena hadir untuk menjawab kebutuhan masyarakat sekitar setiabudi. Keberadaan Game yang semakin marak memerlukan fasilitas yang semakin serius namun juga harus bisa digapai oleh berbagai pihak baik mereka yang pemain maupun penikmat. Dengan hadirnya fasilitas ini, Setiabudi E-Sport Arena akan menjadi salah satu wadah multifungsi bagi penduduk sekitar untuk beristirahat sejenak dan mencari kesenangan dengan bermain game serta bersosialisasi. Fasilitas ini terbangun sebagai akibat dari mulai berkembangnya kompetisis-kompetisi game yang mulai marak di kawasan namun masih terkesan eksklusif dikarenakan wadah pertandingan yang bukan ruang publik. Sehingga Setiabudi E-Sport Arena menciptakan wadah pertandingan yang kontras dengan keadaan pada umumnya agar bisa dinikmati oleh semua orang.

\section{Latar Belakang Sosial}

Keberadaan Kecamatan Setiabudi yang dihimpit oleh keberadaan Segitiga Emas dan dikelilingi oleh proyek-proyek prestisius seperti MRT dan LRT membuat kawasan ini sangat banyak dikunjungi oleh berbagai masyarakat sekitar Jabodetabek, terlebih lagi lokasinya yang berada di pusat kota. Dengan dikelilingi oleh gedung-gedung perkantoran bertingkat tinggi serta berbagai sentra komersial membuat kehidupan dikawasan ini menjadi sangat padat aktivitas. Kepadatan aktivitas ini bisa memicu kehidupan masyarakat khususnya yang berada di kecamatan ini semakin individualis. Terlebih lagi kawasan ini dipenuhi oleh rumah-rumah kost yang penghuninya datang dari luar kecamatan setiabudi yang tidak saling mengenal dengan 
warga lokal ataupun dengan sesama warga pendatang. Sehingga karakteristik masyarakatnya cenderung semakin mengarah ke sikap individualistik dengan semakin banyaknya warga pendatang dan perginya warga lokal. Namun masyarakat di Kecamatan Setiabudi bisa dipersatukan dengan berbagai macam kegiatan yang sudah terjadi di sekitar, seperti olahraga, senam, berkumpul di kafe dan yang baru-baru ini terjadi adalah Live Streaming turnamen game di salah satu kafe di Setiabudi sebagai salah satu latar belakang proyek.

\section{Investigasi Tapak}

- Lokasi: Jalan Karbela Timur, RT 001/ RW 04, Kelurahan Karet, Kecamatan Setiabudi, Kota Jakarta Selatan.

- Peraturan: KDB: 60\% ; KDH : 20\% ; KLB: 1,2 ; KTB : - ; KB : 2 Lantai ; Zona Perumahan

Menggunakan tapak hasil RDTR 2030 dengan pelebaran jalan sekitar tapak sebagai acuan desain sehingga proyek bisa mengantisipasi penggusuran ketika pelebaran jalan terjadi.

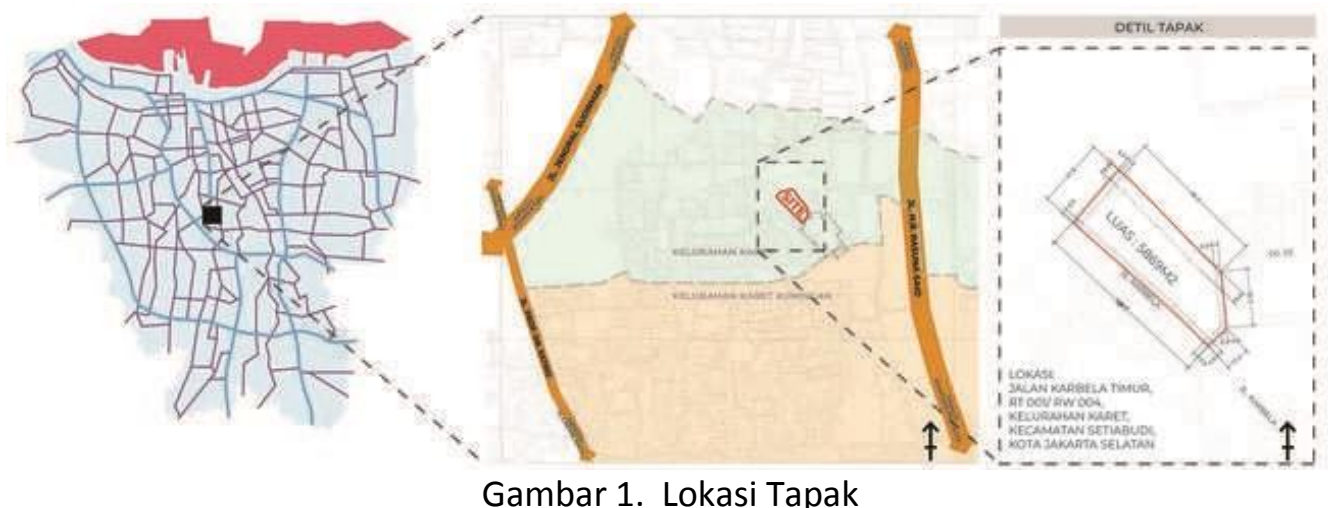

Gambar 1. Lokasi Tapak

Sumber: Peta Zonasi \& Tata Bangunan (RDTR, 2019)

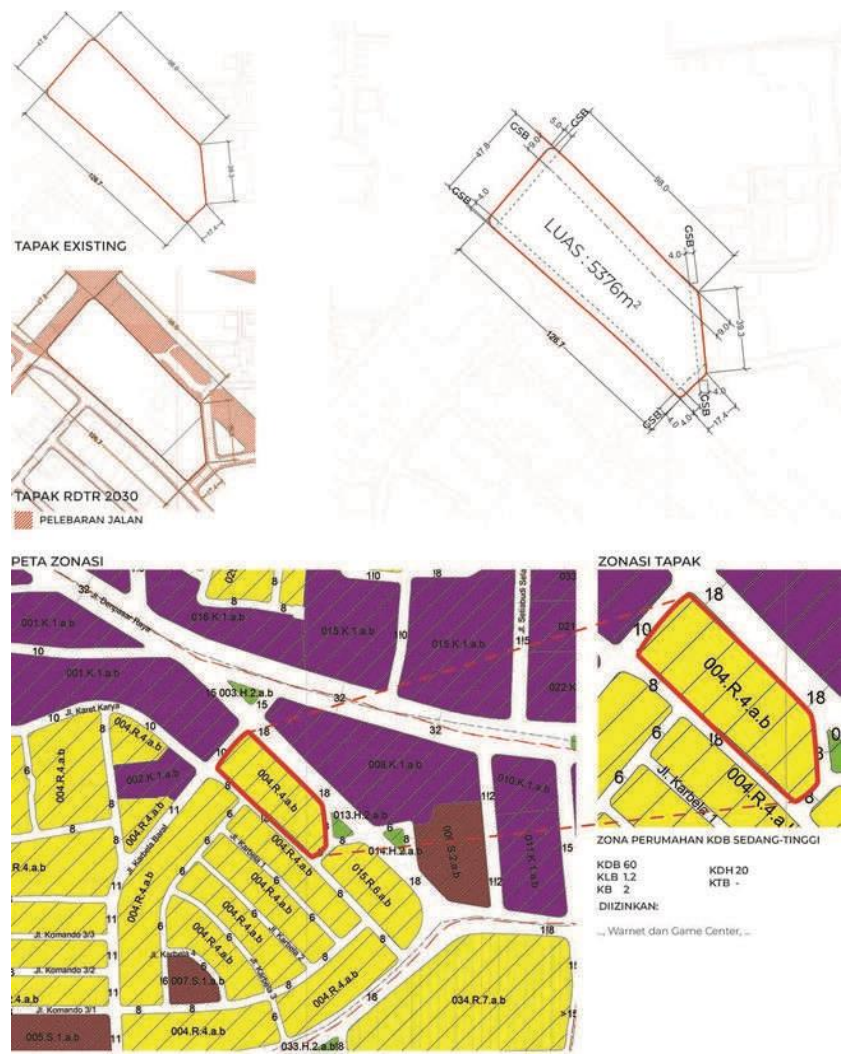

Gambar 2. Peraturan \& Zonasi

Sumber: Peta Zonasi \& Tata Bangunan (RDTR, 2019) 


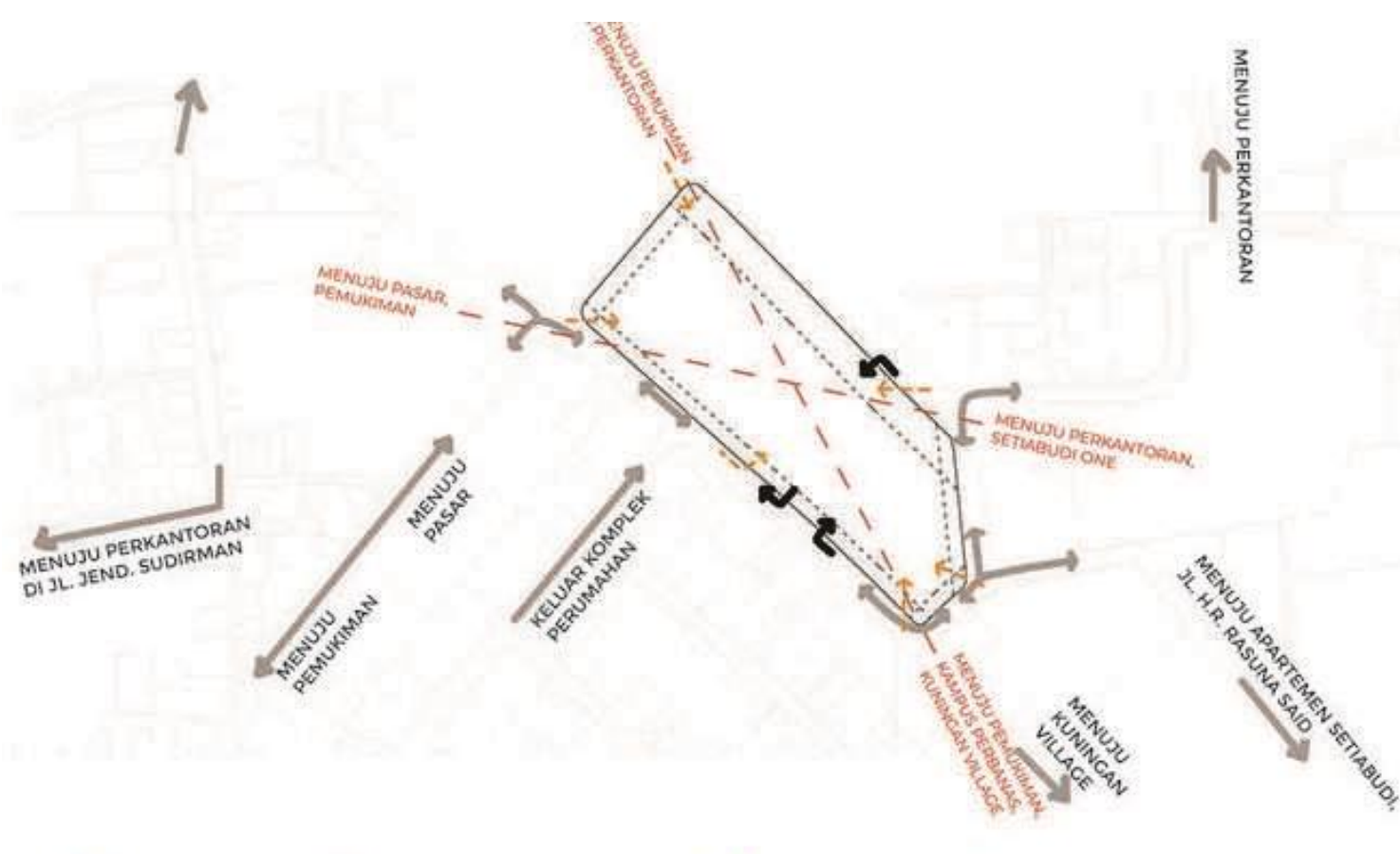

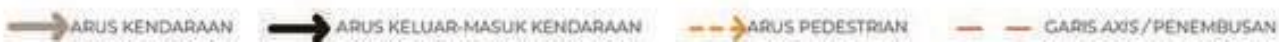

Gambar 3. Sirkulasi sekitar tapak

Sumber: Penulis, 2019

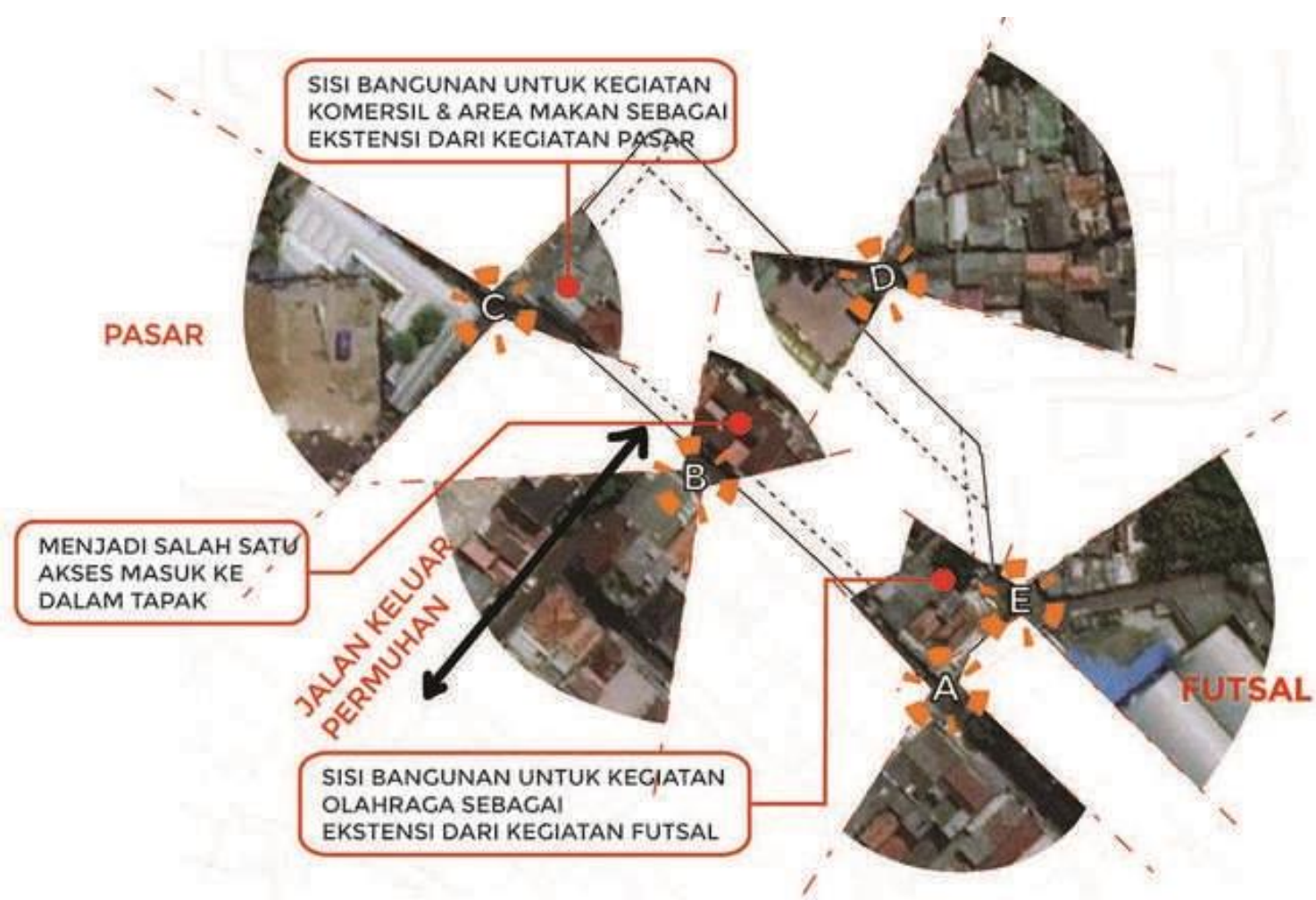

Gambar 4. Penembusan dan Respon Desain

Sumber: Penulis, 2019 
Konsep Perancangan

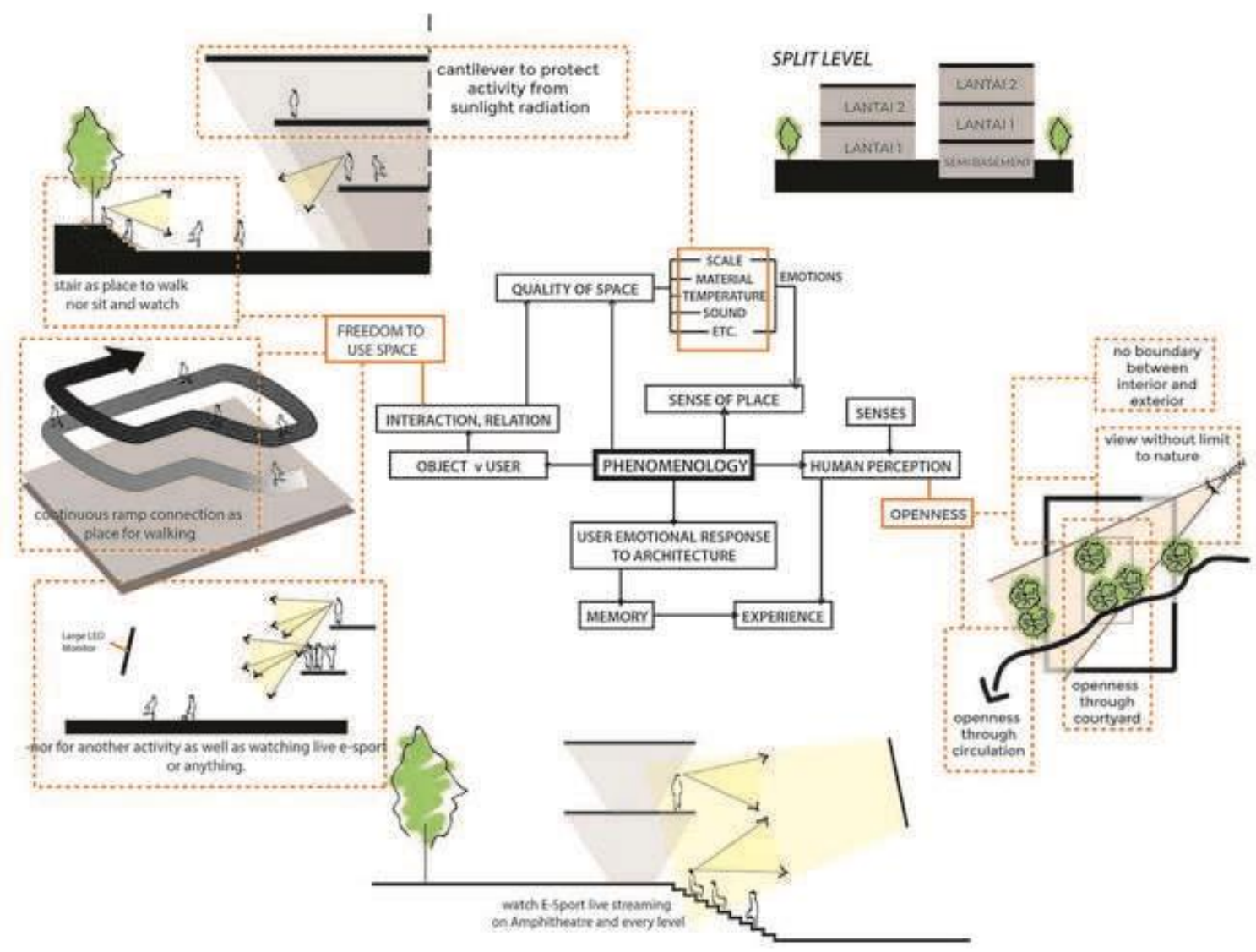

Gambar 5. Konsep \& Metode

Sumber: Penulis, 2019

Penggunaan system split level sebagai akibat kontur tanah yang naik hingga dua meter serta ampiteater semi terbuka yang bisa diakses semua orang sebagai kunci dalam desain.

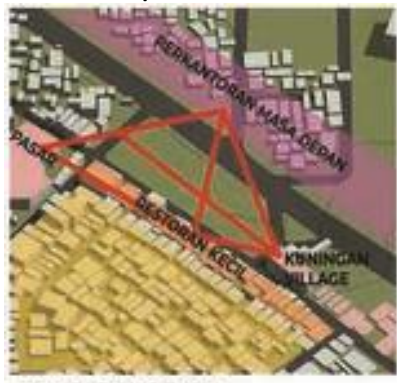

PLACE SHARING

TARAX ONCEUUNG OUEH RUANC QRUANC PUBUK

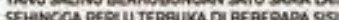

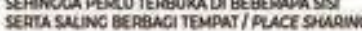

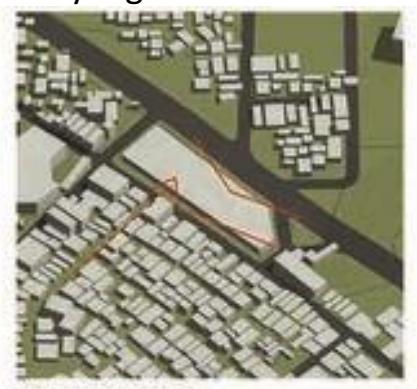

\section{PUBLIC SPACE}

MEMUNDURCON BNCUNUN UNTUK MENCPTANAN AKTMTAS RUANO PUBUK

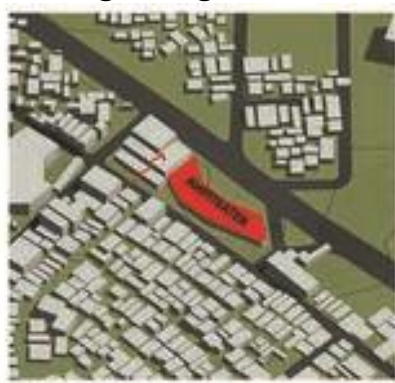

\section{MASS PLACING}

MUSSA BANCUNAN TEREUKA KE ARAH PEMLNOMAI SERBA MENEMPATCAN AMPIEATEG SEBAEA VOCA

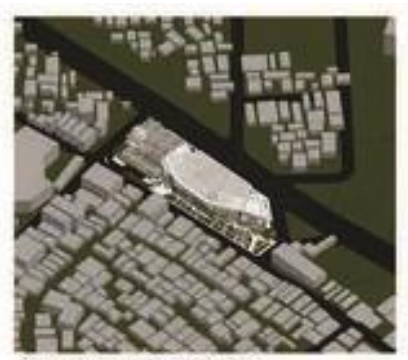

GATHERING SPACE

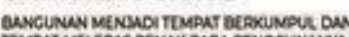
ENOAT MEL LPAS DENWX DARA PENCCONWWW

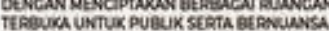
MENMEUNCXAN

Gambar 6. Proses Gubahan

Sumber: Penulis, 2019 
Perancangan dalam proyek ini mengacu kepada bagaimana sebuah wadah pertandingan yang biasanya bisa dinikmati secara eksklusif menjadi inklusif namun tetap menarik penonton setianya. Tujuannya adalah menciptakan sebuah arena pertandingan di kawasan Setiabudi yang juga bisa dinikmati siapapun sekaligus memperkenalkan pertandingan E-Sport itu sendiri kepada masyarakat luas. Arena Pertandingan selalu berada berdekatan dengan ruang-ruang publik yang juga berfungsi sebagai Shared Place sehingga semua orang yang berada di luar arena dapat menyaksikan pertandingan di dalamnya. Ruang-ruang publik yang berada di dalam proyek terbuka kearah fasilitas-fasilitas penunjang kawasan sehingga pemakaian ruang luarnya bisa bersama-sama (Shared Place). Setiap lantainya bisa menikmati pertandingan yang terjadi di arena dengan menggunakan jarak tertentu dari bangunan ke layar LED/ Videotron Pertandingan Olahraga Elektronik /E-Sport.

\section{Program}

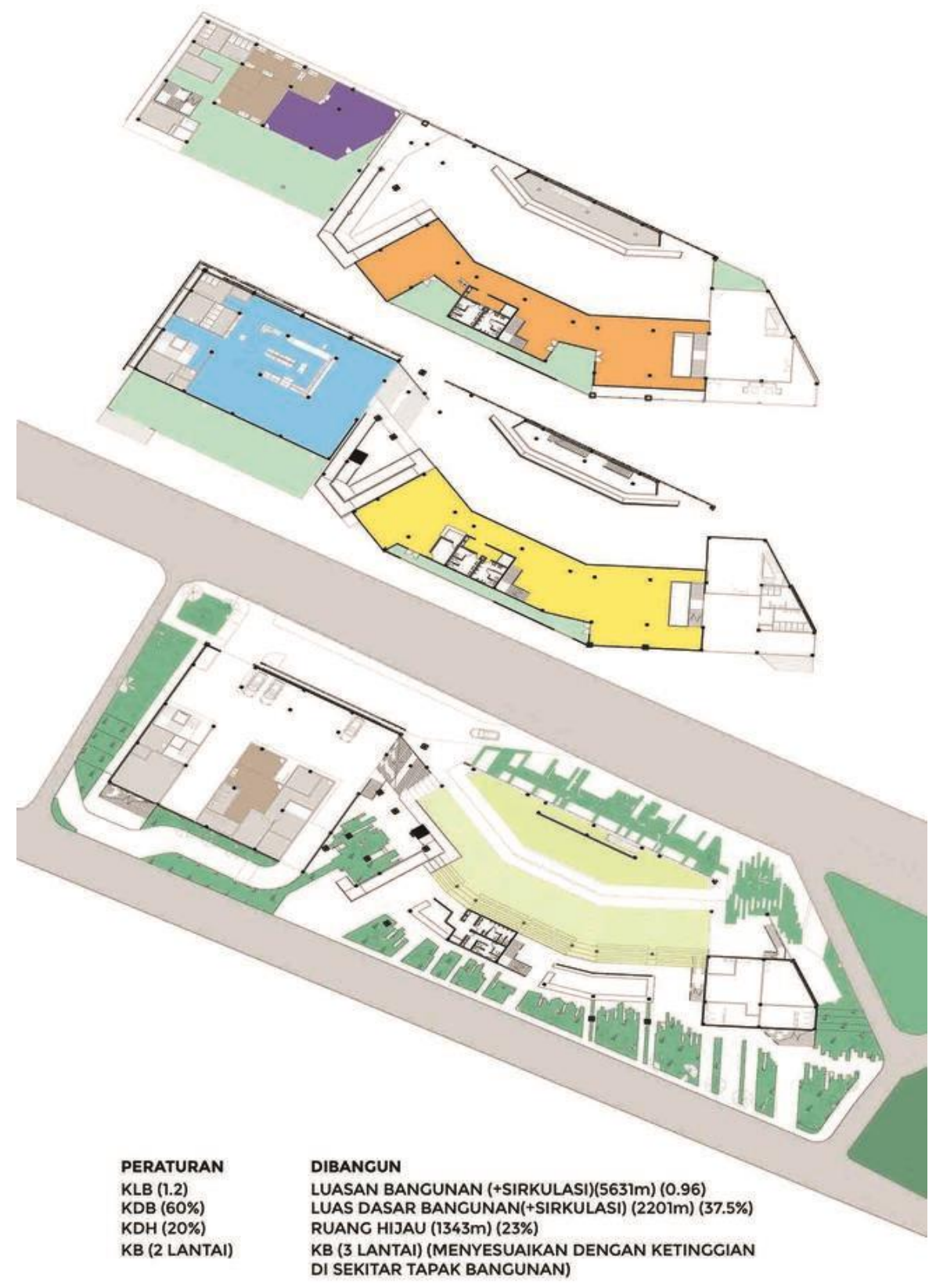

Gambar 7. Program \& Zoning

Sumber: Penulis, 2019 
LANTAI 3A

\begin{tabular}{|l} 
KAFE $(122 \mathrm{~m})$ \\
PANTRY $(28 \mathrm{~m})$ \\
KANTOR $(116 \mathrm{~m})$ \\
KAFE OUTDOOR $(196 \mathrm{~m})$ \\
GUDANG $(15 \mathrm{~m})$ \\
TOILET $(32 \mathrm{~m})$ \\
RUANC ISTIRAHAT KARYAWAN $(24 \mathrm{~m})$ \\
RUANG PANEL $(3 \mathrm{~m})$ \\
JANITOR $(3 \mathrm{~m})$ \\
RUANC LATIHAN $(102 \mathrm{~m})$ \\
TERAS $(73 \mathrm{~m})$ \\
TOTAL $(616 \mathrm{~m})$
\end{tabular}

LANTAI 2A

\begin{tabular}{|l} 
LANTAI 2A \\
RESTORAN $(350 \mathrm{~m})$ \\
OPEN KITCHEN $(96 \mathrm{~m})$ \\
AREA MAKAN OUTDOOR $(240 \mathrm{~m})$ \\
GUDANG $(15 \mathrm{~m})$ \\
TOILET $(72 \mathrm{~m})$ \\
RUANG ISTIRAHAT KARYAWAN $(24 \mathrm{~m})$ \\
RUANC PANEL $(3 \mathrm{~m})$ \\
JANITOR $(3 \mathrm{~m})$ \\
\hline \\
\hline \\
\hline \\
\hline \\
LOUNGE PESERTA $(102 \mathrm{~m})$ \\
TOBAL PESERTA $(73 \mathrm{~m})$ \\
\hline
\end{tabular}

LANTAI IA

\begin{tabular}{l} 
LANTAI IA \\
\hline PARKIR (9MOBIL/32MOTOR) $(520 \mathrm{~m})$ \\
HOUSEKEEPING $(43 \mathrm{~m})$ \\
RUANC KEAMANAN $(16 \mathrm{~m})$ \\
MUSHOLLA $(24 \mathrm{~m})$ \\
TOILET KARYAWAN $(30 \mathrm{~m})$ \\
GENSET $(60 \mathrm{~m})$ \\
GUDANC SOLAR $(4 \mathrm{~m})$ \\
TRAFO $(16 \mathrm{~m})$ \\
PANEL INDUK $(2 \mathrm{~m})$ \\
LOADING DOCK $(20 \mathrm{~m})$ \\
GWT $(24 \mathrm{~m})$ \\
STP $(16 \mathrm{~m})$ \\
WTP $(16 \mathrm{~m})$ \\
RUANC POMPA $(8 \mathrm{~m})$ \\
RUANG PERSIAPAN $(43 \mathrm{~m})$ \\
RUANC GANTI \& TOILET $(60 \mathrm{~m})$ \\
RUANC KONTROL $(8 \mathrm{~m})$ \\
GUDANC ARENA $(54 \mathrm{~m})$ \\
DIRECT SERVICE $(20 \mathrm{~m})$ \\
TOTAL $(982 \mathrm{~m})$
\end{tabular}

LANTAI 3B

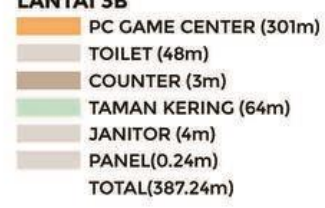

LANTAI 2B

\begin{tabular}{|l}
\hline LANTAI 2B \\
PC GAME CENTER $(301 \mathrm{~m})$ \\
TOILET $(48 \mathrm{~m})$ \\
KANTOR $(23 \mathrm{~m})$ \\
TAMAN KERING $(32 \mathrm{~m})$ \\
TANITOR $(4 \mathrm{~m})$ \\
PANEL $(0.24 \mathrm{~m})$ \\
TOTAL $(391.24 \mathrm{~m})$
\end{tabular}

LANTAI 1B

\begin{tabular}{l} 
LANTAI IB \\
E-SPORT ARENA $(234 \mathrm{~m})$ \\
AREA DUDUK/AMPITEATER $(582 \mathrm{~m})$ \\
TOILET $(48 \mathrm{~m})$ \\
\hline \\
RETAIL MAKANAN $(66 \mathrm{~m})$ \\
JANITOR $(4 \mathrm{~m})$ \\
PANEL $(0.24 \mathrm{~m})$ \\
\hline PUSAT INFORMASI $(32 \mathrm{~m})$ \\
TOBBY $(48 \mathrm{~m})$ \\
TOTAL $(1018.24 \mathrm{~m})$ \\
\\
TAMAN $(1343 \mathrm{~m})$ \\
LUASAN PROGRAM $(4693 \mathrm{~m})$
\end{tabular}

Gambar 8. Detil Program \& Zoning Sumber: Penulis, 2019

\section{Gambar Kerja}

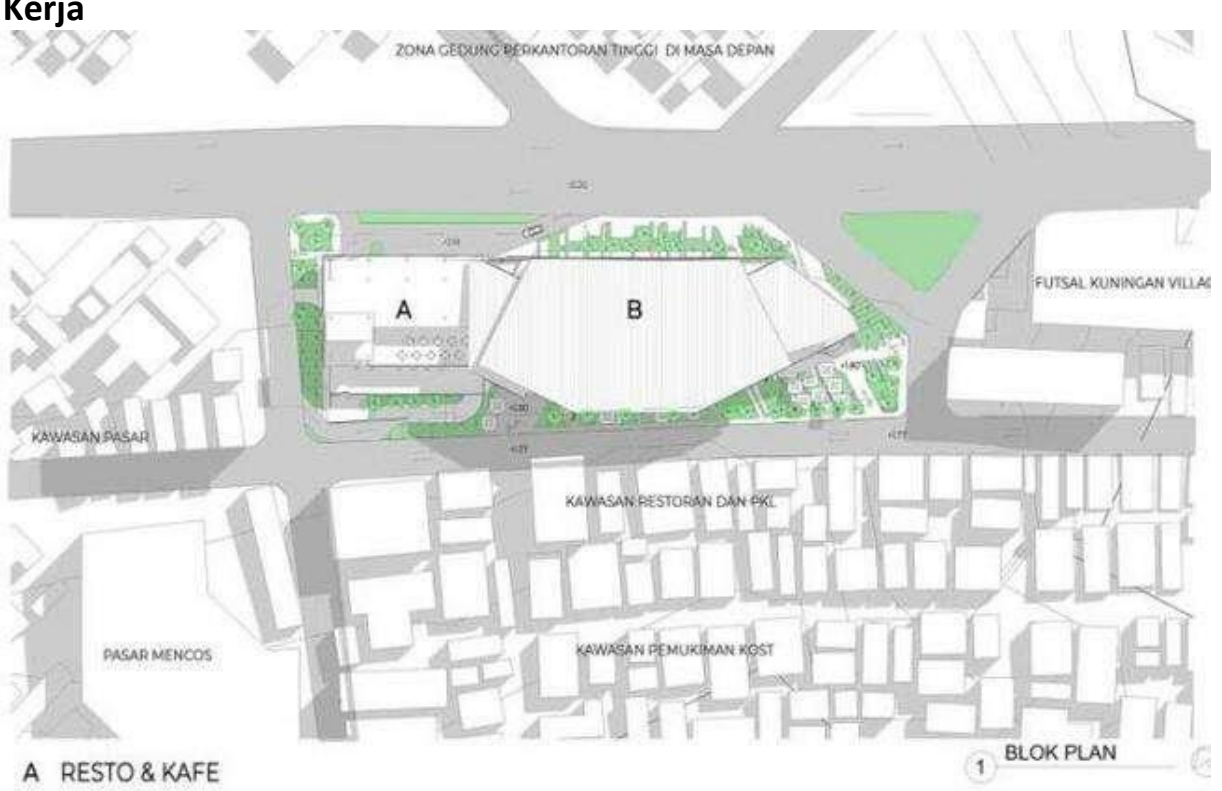

B E-SPORT ARENA

Gambar 9. Blok Plan

Sumber: Penulis, 2019 
Sisi selatan bangunan memiliki halaman terbuka yang menerus hingga ke dalam arena dan juga berfungsi sebagai ekstensi tempat makan dari restoran-restoran yang ada di sisi selatan bangunan. Ruang terbuka hijau juga mengelilingi sekitar bangunan untuk memberi kesan sejuk dari luar.

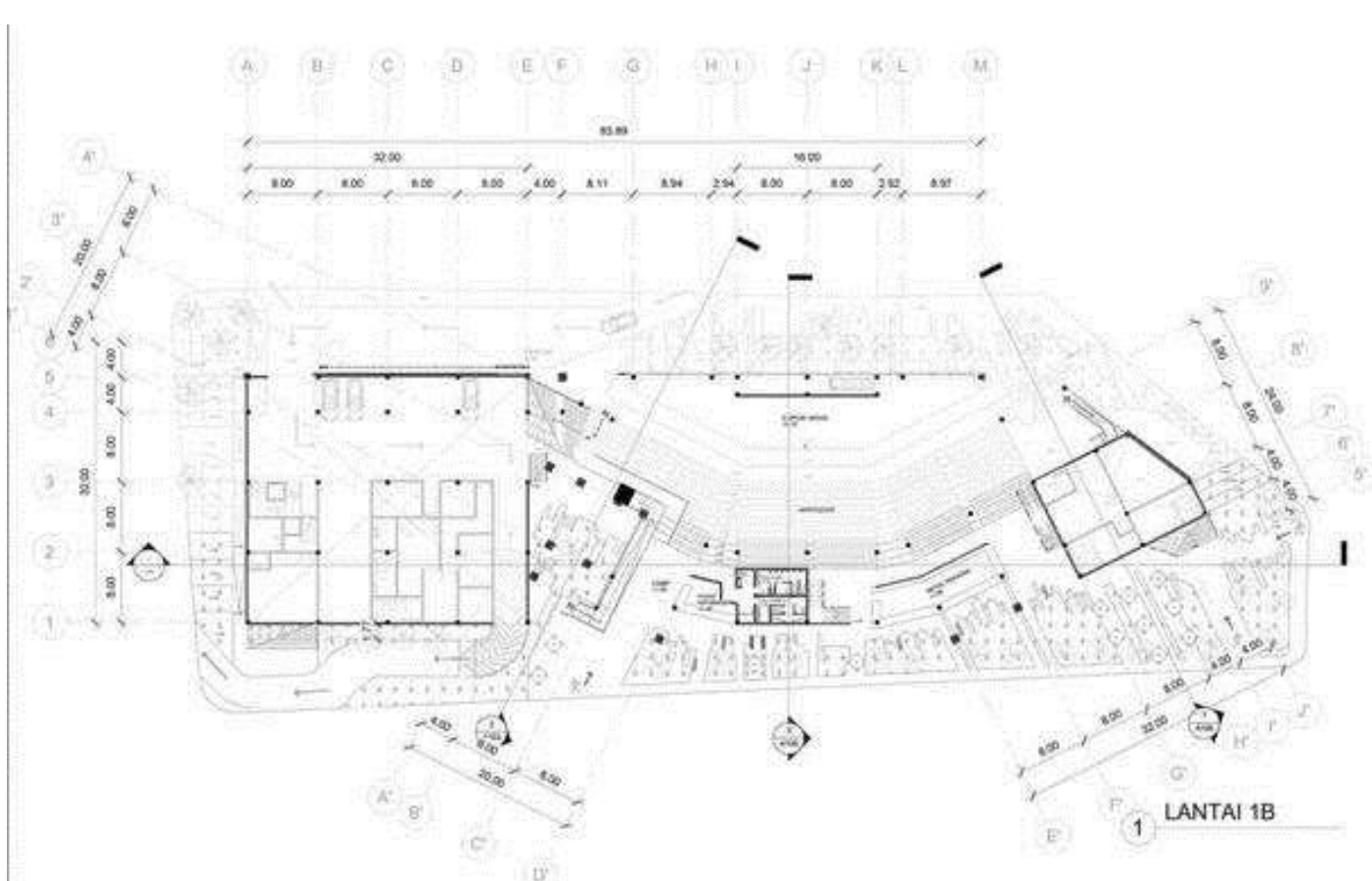

Gambar 10. Denah Lantai 1A-1B

Sumber: Penulis, 2019

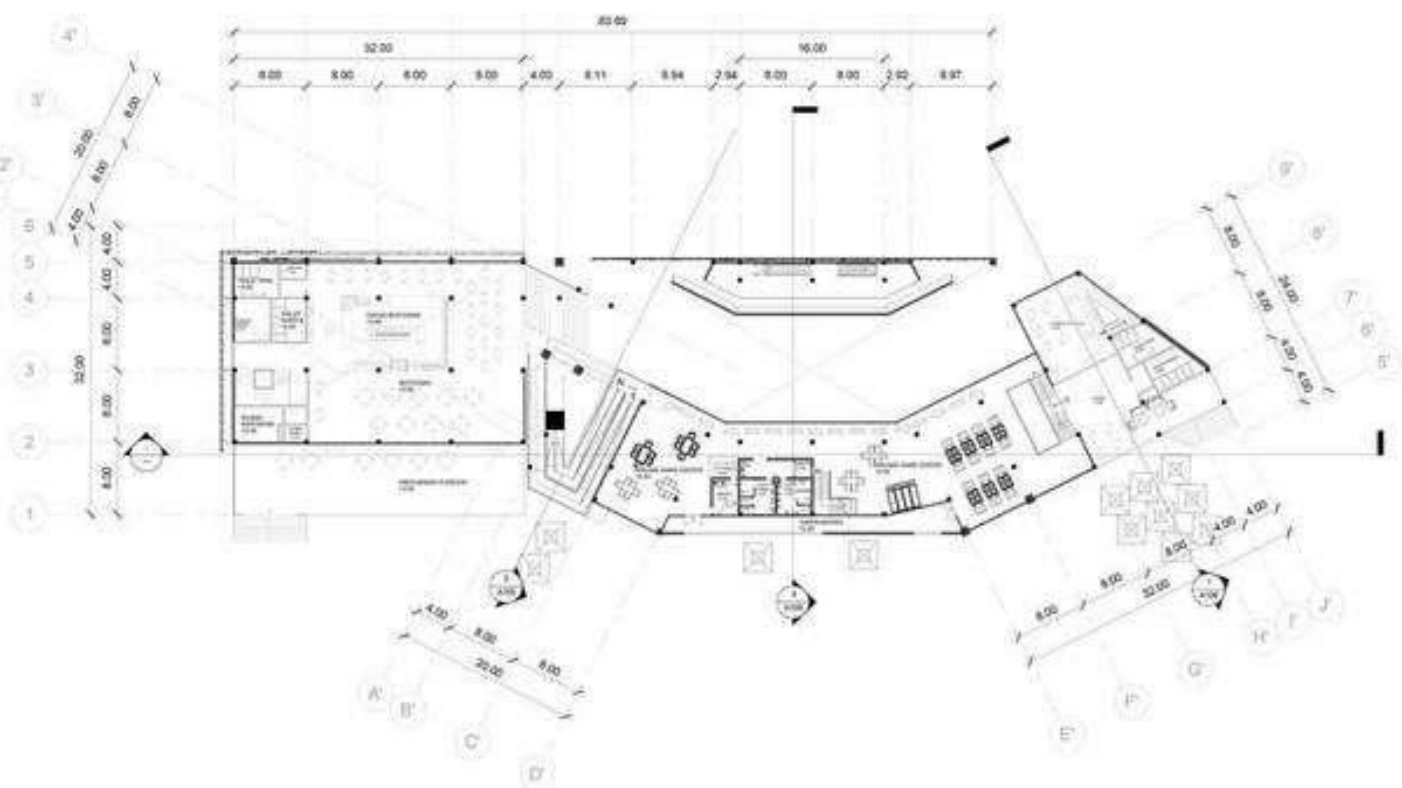

1 LANTAI 2B

Gambar 11. Denah Lantai 2A-2B

Sumber: Penulis, 2019 


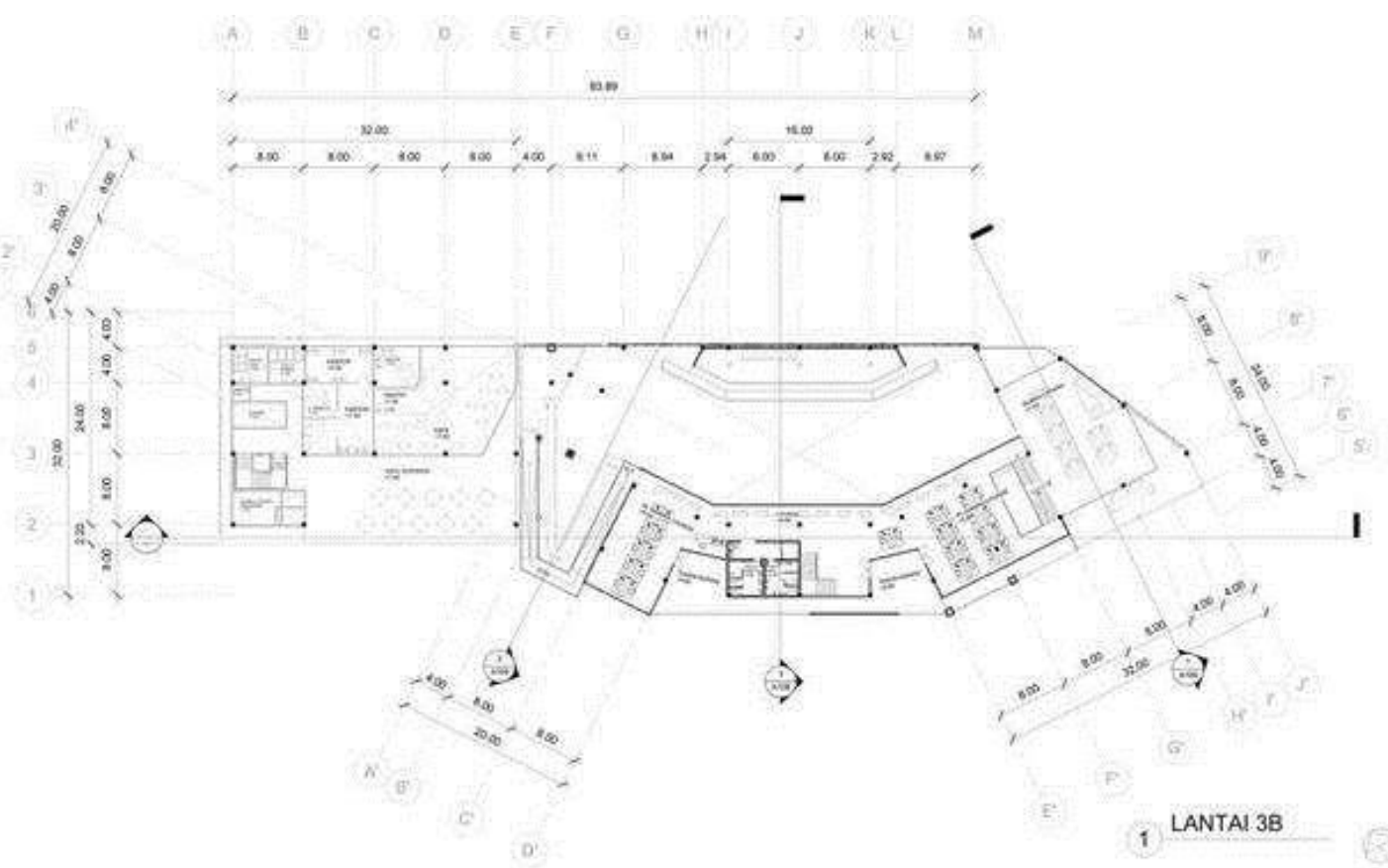

Gambar 12. Denah Lantai 3A-3B

Sumber: Penulis, 2019

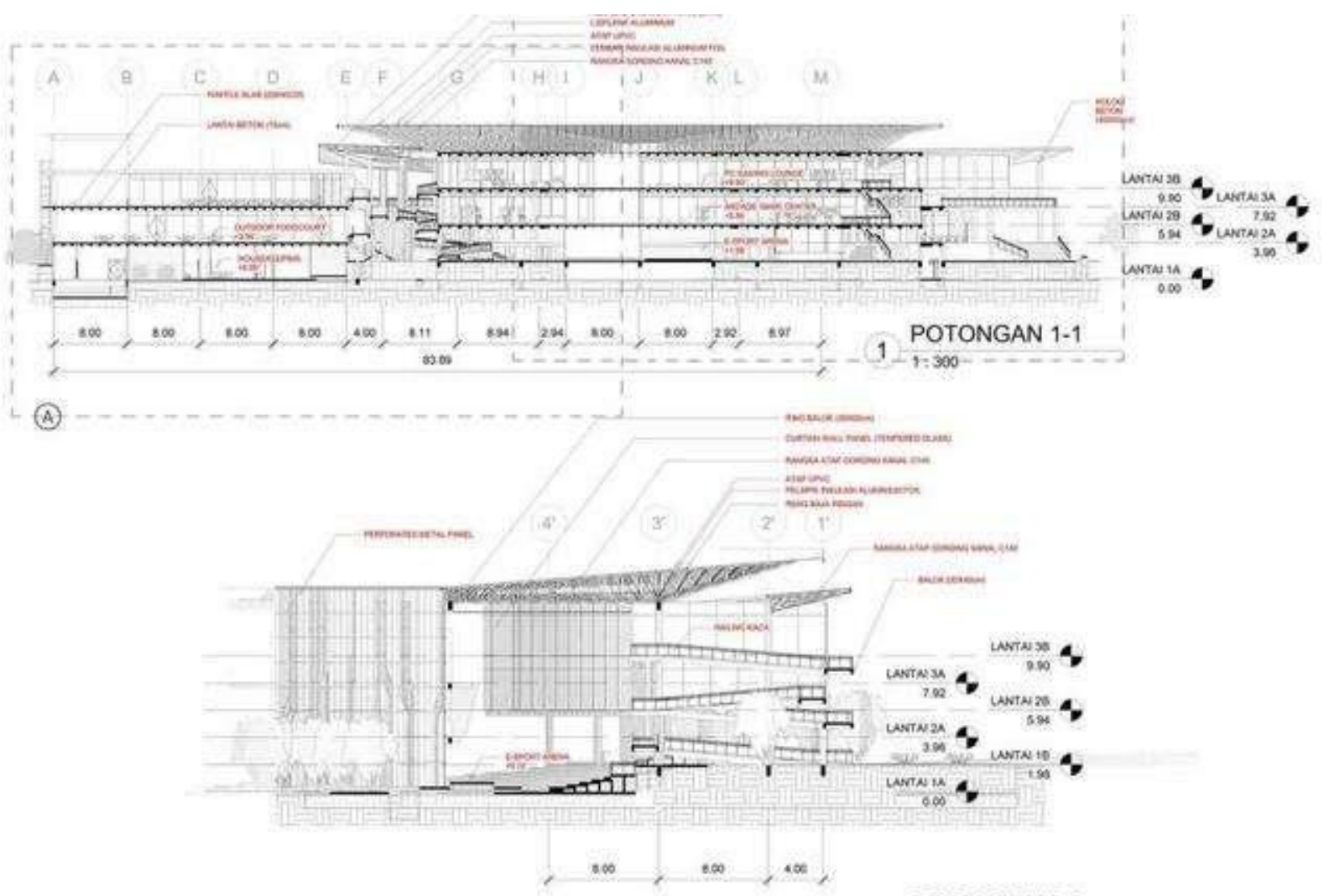

Gambar 13. Potongan

POTONGAN 2-2

Sumber: Penulis, 2019 
Bangunan menggunakan sistem split-level karena kontur yang ada di tapak mencapai 2,1 meter. Bangunan dibagi menjadi tiga massa sebagai akibat dilatasi bangunan untuk menghindari kerusakan struktur akibat panjang bangunan.

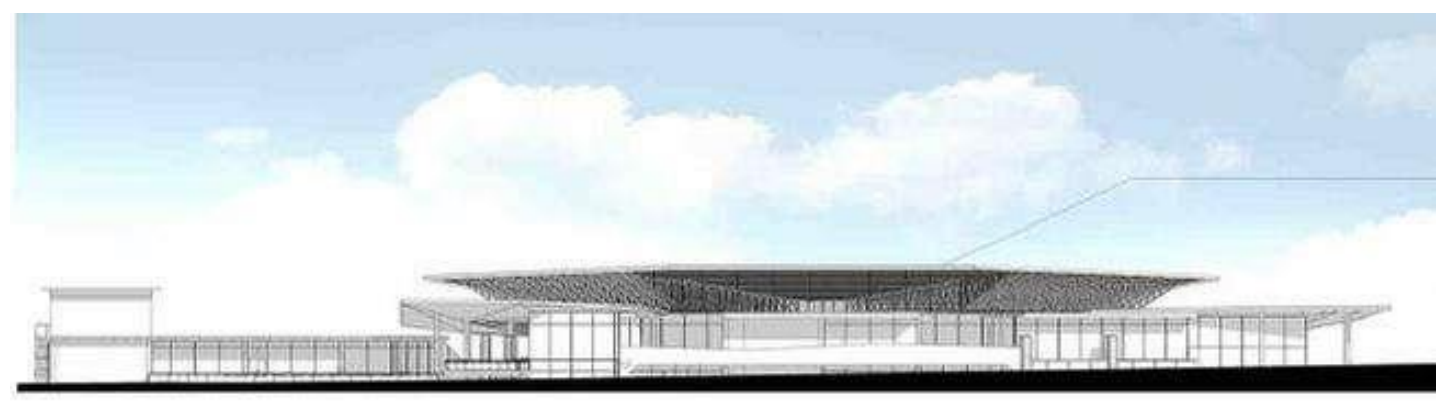

1 Tampak Depan

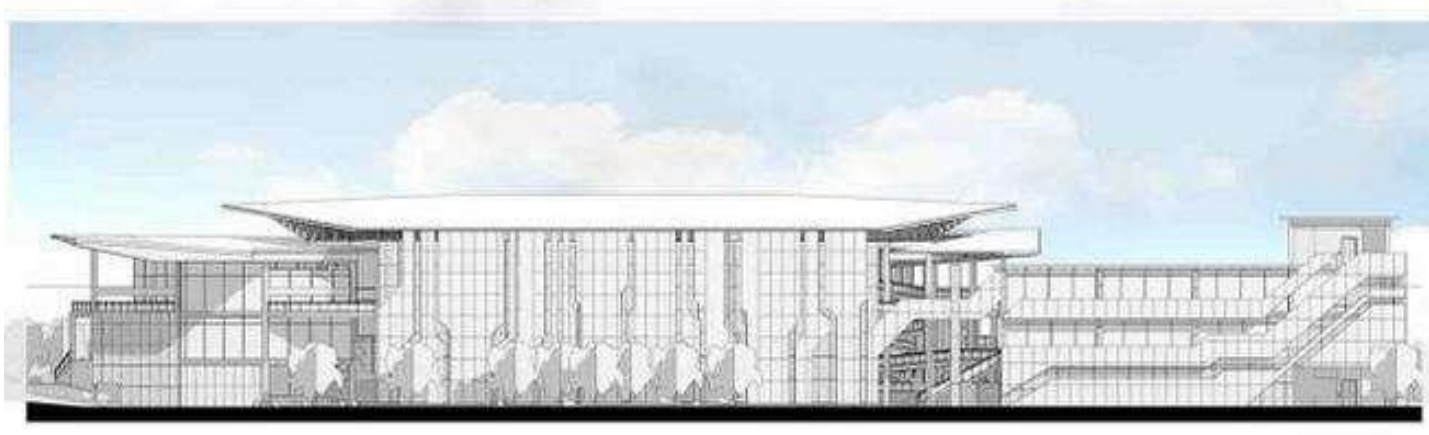

2 Tampak Belakang

Gambar 14: Tampak Depan Belakang Sumber: Penulis, 2019
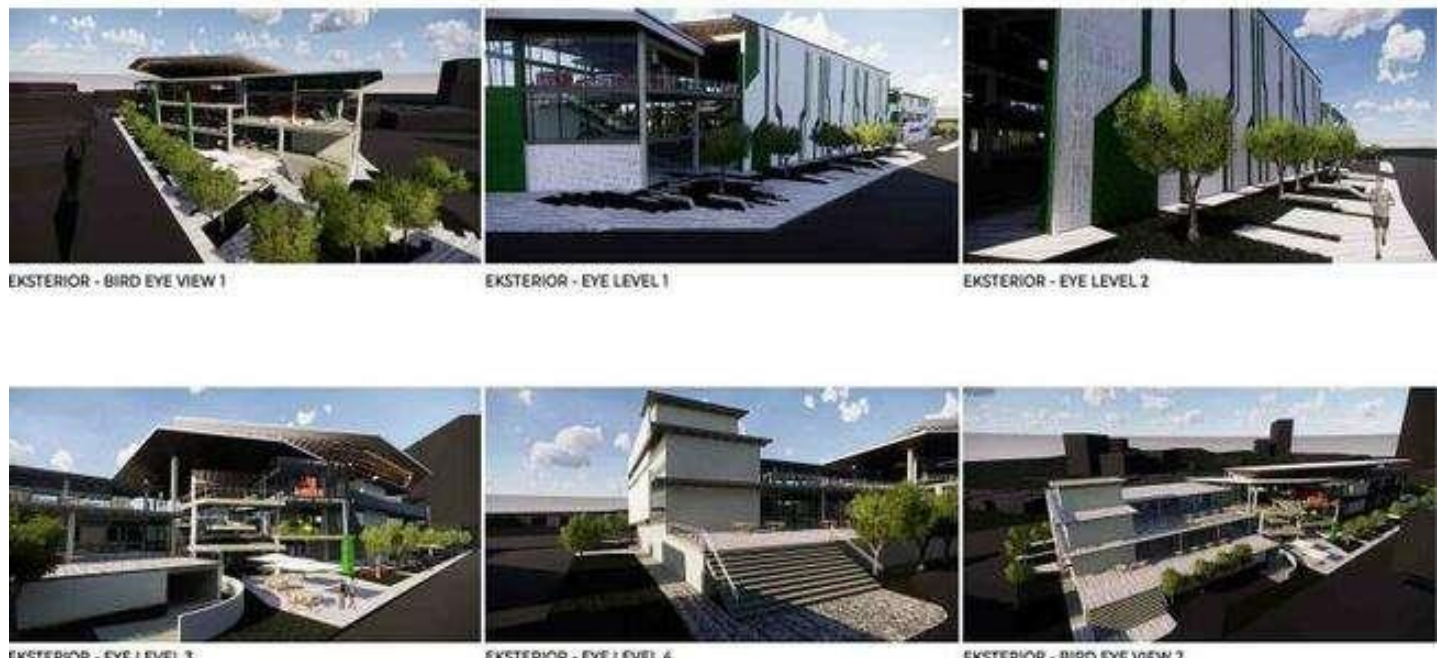

Gambar 15. Persepktif

Sumber: Penulis, 2019 

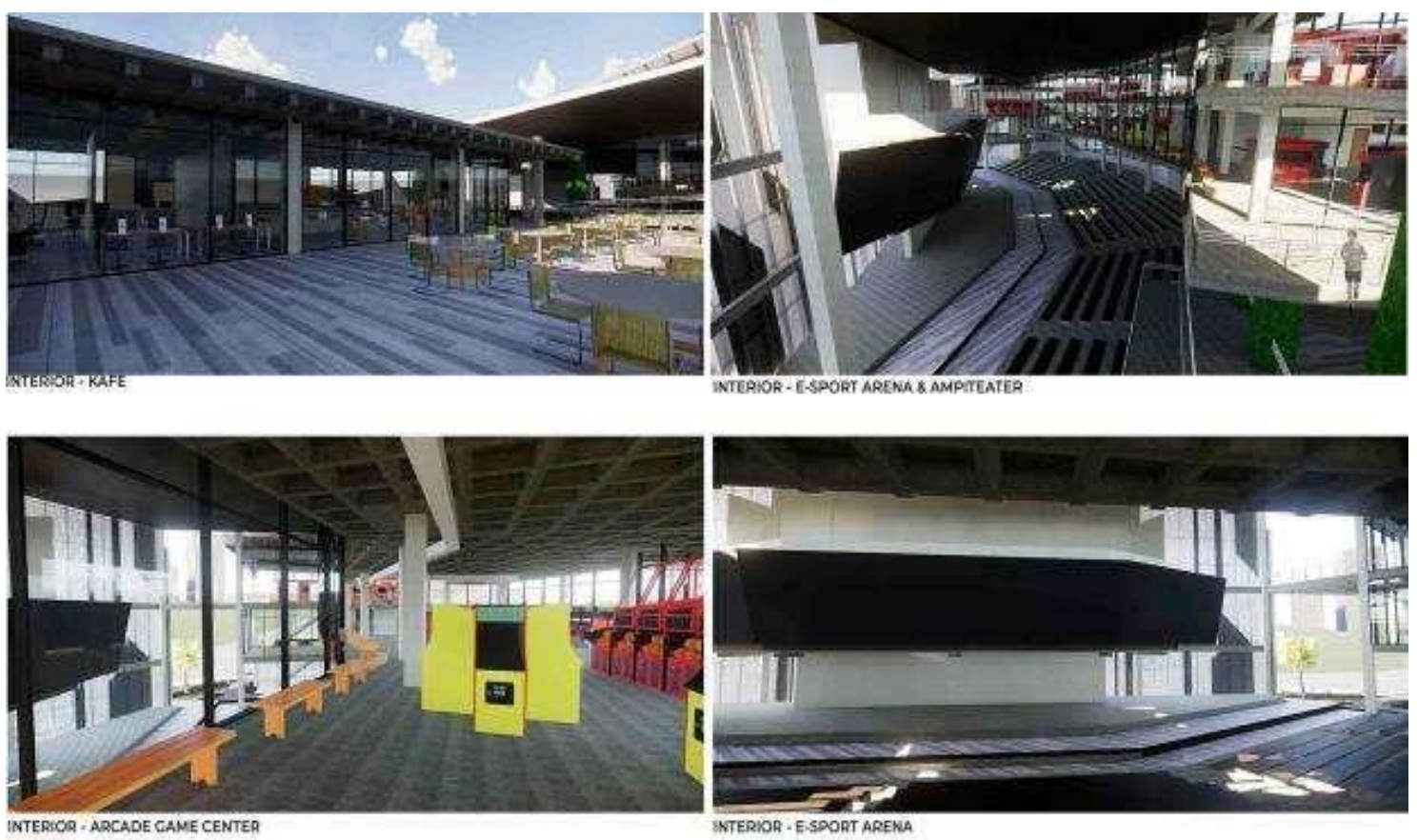

Gambar 16. 3D Interior

Sumber: Penulis, 2019

\section{KESIMPULAN \& SARAN}

\section{Kesimpulan}

Esport Arena membutuhkan kondisi tapak tertentu sesuai dengan tipologi dari ampiteater ataupaun auditorium dalam kata lain memerlukan tapak yang luas. Peletakan arena juga perlu dipertimbangkan di lokasi yang tidak langsung bersinggungan dengan jalan umum dikarenakan memerlukan kondisi sedemikian rupa sehingga audio visual menjadi terjaga. Keberadaan kontur tanah di tapak dimanfaatkan menjadi sebuah area ampiteater sehingga mengurangi proses cut \& fill tanah. Peraturan menyatakan bahwa kawasan ini hanya bisa dibangun sampai dua lantai namun dibangun menjadi tiga lantai split-level dengan asumsi mengajukan penambahan ketinggian dikarenakaan ketinggian bangunan di sekitar tapak adalah tiga sampai empat lantai. Dalam desain arena esport sangat dibutuhkan fasilitas-fasilitas pendukung yang selaras dengan program seperti area permainan dan kafe-kafe internet sebagai cara memancing pengguna untuk dating khusunya para penikmat permainan. Keberadaan fasilitas itu harus bisa dirasakan menyatu dengan program arena secara mulus/ seamless dengan mengadopsi konsep terbuka sesuai teori third place yang telah dipelajari. Esport tidak memiliki batas antara pemain dan penonton atau kurang lebih memiliki kedekatan yang lebih erat disbanding olahraga lainnya sehingga memungkinkan keterbukaan dari sisi desain anatara panggung dan bangku penonton. Penggunaan detail-detail pada bangunan haruslah bernuansa gaming serta harus menunjukkan kehadiran revolusi industri 4.0 karena esport merupakan salahsatu produk yang berkembang di dalamnya

\section{Saran}

Dalam menghadapi desain arena esport diperlukan kelihaian dalam mengolah antara arena serta fasilitas pendukung sehingga keberadaannya menjadi satu kesatuan, dimana semua orang bisa merasakan nuansa pertandingan dimanapun dia berada. Selain itu perlu memperhatikan bentuk tapak serta orientasi arena serta kondisi alam sekitar (pencahayaan alami, pengudaraan, kebisingan) sehingga tidak mengganggu peralatan elektronik/ pemborosan listrik terutama pada bagian arena. 


\section{REFERENSI}

Anon. (2013). The Community Center. UAJY.

http://e-journal.uajy.ac.id/16093/3/TA151772.pdf. (25 Agustus 2019)

Banyai, F, Mark D.Griffiths, Orsolya Kiraly, Zsolt Demetrovics. 2018. "The psychology of esports: A systematic literature review". Notthingham Trent Institutional Repository. https://core.ac.uk/download/pdf/151392545.pdf . (08 Januari 2020)

Gaudiosi, John. (2013, April)."Team Evil Geniuses Manager Anna Prosser Believes More Female Gamers Will Turn Pro". Forbes. https://www.forbes.com/sites/johngaudiosi/2012/04/28/team-evil-geniuses-manageranna-prosser-believes-more-female-gamers-will-turn-pro/\#45ebfcfa1383 . (28 Agustus 2019)

Kantor Kecamatan Setiabudi. "Kecamatan Setiabudi Dalam Angka 2018". Jakarta. BPS Jakarta Selatan.https://jakselkota.bps.go.id/publication/download.html?nrbvfeve=NGUyYjBhNDEz N2RINWJhM2E0MjY1NGEy\&xzmn=aHROcHM6Ly9qYWtzZWxrb3RhLmJwcy5nby5pZC9wdWJ saWNhdGlvbi8yMDE2LzA4LzI3LzRIMmIwYTQxMzdkZTViYTNhNDI2NTRhMi9zZXRpYWJ1ZGkt ZGFsYWOtYW5na2EtMjAxNi5odG1s\&twoadfnoarfeauf=MjAxOSOwOCOyNyAyMzoONzoyMQ \%3D\%3D (20 Agustus 2019)

Lynch, P. (2017). MVRDV Create Park Topped Community Center for Shanghai Neighborhood. https://www.archdaily.com/881800/mvrdv-create-park-topped-community-center-forshanghai-neighborhood?ad_source=search\&ad_medium=search_result_all. (28 Agustus 2019)

Oldenburg, R. (1999). The Great Good Place: Cafés, Coffee Shops, Bookstores, Bars, Hair Salons, and Other Hangouts at the Heart of a Community. United States: Marlowe.

Places, Healthy Spaces \&. $\quad 2009$. "Parks \& Open Spaces". Australia. Healthy Spaces \& Places.https://www.healthyplaces.org.au/userfiles/file/Parks\%20and\%200pen\%20Space\%2 OJune09.pdf\#targetText=Parks\%20and\%200pen\%20Space,or\%20urban\%20storm\%20water \%20management. (28 Agustus 2019)

Prescott, Jay, Kurt Eisele. 2019. "Guide to Esport". UBTech. https://naecad.org/wpcontent/uploads/2019/06/Esports-Guide-UBTech-Conference-6-10-19-1.pdf . (09 Januari 2019)

RDTR DKI Jakarta. 2014. "Peta Zonasi, Kecamatan Setiabudi, Kota Administrasi Jakarta Selatan". Jakarta: Pemprov DKI Jakarta.

Slamet, Suherman.N/A. "Modul Bermain" dalam Jurnal Pendidikan Olahraga. Jakarta. UPI. http://file.upi.edu/Direktori/FPOK/JUR._PEND._OLAHRAGA/197603082005011-

SUHERMAN_SLAMET/modul_bermain_08/bab_6_teori_bermain.pdf. (28 Agustus 2019)

SMMNRA. 2009. "Review of Relevant Literature". USA. National Park Service. https://www.nps.gov/samo/learn/management/upload/02RelevantLit.pdf . (28 Agustus 2019)

Sumardjito. 1999. "Permasalahan Perkotaan dan Kecenderungan Perilaku Individualis Penduduknya".Yogyakarta. FPTK IKIP Yogyakarta. https://media.neliti.com/media/publications/95596-none-027efa16.pdf. (22 Januari 2019)

Syani, A. (2012). Sosiologi Skematika, Teori, dan Terapan. Jakarta. PT Bumi Aksara, hlm. 155. 